OPEN ACCESS

Edited by:

Christophe Le May,

Agrocampus Ouest, France

Reviewed by:

Sébastien Guyader,

INRA, France

Ivan Sache,

AgroParisTech Institut des Sciences

et Industries du Vivant et

de L'environnement, France

*Correspondence:

Diego F. Rincon

drincon@corpoica.org.co

Specialty section:

This article was submitted to Crop Science and Horticulture,

a section of the journal

Frontiers in Plant Science

Received: 02 May 2017 Accepted: 08 September 2017 Published: 25 September 2017

Citation:

Cuadros DF, Hernandez A, Torres MF, Torres DM, Branscum AJ

and Rincon DF (2017) Vector

Transmission Alone Fails to Explain the Potato Yellow Vein Virus Epidemic

among Potato Crops in Colombia.

Front. Plant Sci. 8:1654

doi: 10.3389/fpls.2017.01654

\section{Vector Transmission Alone Fails to Explain the Potato Yellow Vein Virus Epidemic among Potato Crops in Colombia}

\author{
Diego F. Cuadros ${ }^{1,2}$, Anngie Hernandez ${ }^{3}$, Maria F. Torres ${ }^{4}$, Diana M. Torres ${ }^{3}$, \\ Adam J. Branscum ${ }^{5}$ and Diego F. Rincon ${ }^{3 *}$ \\ 1 Department of Geography and Geographic Information Science, University of Cincinnati, Cincinnati, OH, United States, \\ ${ }^{2}$ Health Geography and Disease Modeling Laboratory, University of Cincinnati, Cincinnati, $\mathrm{OH}$, United States, ${ }^{3}$ Corporación \\ Colombiana de Investigación Agropecuaria (Corpoica), Centro de Investigación Tibaitatá, Mosquera, Colombia, \\ ${ }^{4}$ Department of Biological Sciences, University of Cincinnati, Cincinnati, OH, United States, ${ }^{5}$ Biostatistics Program, Oregon \\ State University, Corvallis, OR, United States
}

The potato yellow vein disease, caused by the potato yellow vein virus (PYW), is a limiting potato disease in northern South America. The virus can be transmitted either by the greenhouse whitefly (GWF), Trialeurodes vaporariorum (Westwood) (Hemiptera: Aleyrodidae), or through vegetative propagules, such as infected tubers. Recently, GWF populations have been spotlighted as one of the main drivers of PYW re-emergence, and consequently, PYV management has been predominantly directed toward vector control, which is heavily based on insecticide use. However, the drivers of the PYW outbreaks as well as the contribution of GWF populations on the spread of PYW among potato crops are still not completely understood. This study aims to assess the role of the GWF as a driver of the PYW epidemic in the potato-producing areas in Colombia, one of the countries more severely affected by the PYW epidemic, and whose geography allows the study of the spatial association between the vector and the disease epidemic across a wide altitude range. The geographical clusters where the PYW epidemic is concentrated, as well as those of farms affected by the GWF were identified using a novel spatial epidemiology approach. The influence of altitude range on the association between PYV and T. vaporarioum was also assessed. We found a relatively poor spatial association between PYV epidemic and the presence of the GWF, especially at altitudes above 3,000 m above mean sea level. Furthermore, GWF populations could only explain a small fraction of the extent of the PYW epidemic in Colombia. Movement of infected seed tubers might be the main mechanism of dispersion, and could be a key driver for the PYV infection among potato crops. Agricultural policies focused on improving quality of seed tubers and their appropriate distribution could be the most efficient control intervention against PYV dispersion.

Keywords: PYVV epidemics, greenhouse whitefly, Trialeurodes vaporariorum, vegetative propagules, spatial epidemiology 


\section{INTRODUCTION}

Potato yellow vein disease (PYVD), caused by the potato yellow vein virus (PYVV), was first reported in Colombia in 1943 (Salazar et al., 2000). This virus is classified as a Crinivirus, a genus that includes the whitefly transmitted members of the family Closteroviridae (Wisler et al., 1998; Salazar et al., 2000). Multiple studies report that PYVV can be transmitted by the greenhouse whitefly (GWF), Trialeurodes vaporariorum (Westwood) (Hemiptera: Aleyrodidae) (Salazar et al., 2000; Barragan and Guzmán-Barney, 2014), but it can also be spread through vegetative propagules such as infected tubers (Salazar et al., 2000; Sastry, 2013). PYVD symptoms are described as vein yellowing with green interveinal spaces, which are associated with a decrease of photosynthetic capacity, plant vigor, and early senescence (Salazar et al., 2000; Chávez et al., 2009). Affected plants produce significantly less and smaller tubers, reducing yield by $30-50 \%$ (Saldarriaga et al., 1988; Tzanetakis et al., 2014). PYVV distribution used to be restricted to Colombia and Ecuador, and had been considered as a re-emergent, local, sporadic epidemic with negligible effects on regional potato yields for more than six decades (Salazar et al., 2000). However, the outbreaks recorded during the last 20 years have reduced significantly potato yields in entire regions of Colombia and Ecuador (Salazar et al., 2000; ICA, 2014), and the virus has been reported throughout potato-producing areas in the Andes region of Venezuela and Peru since 1996 (Salazar et al., 2000; Tzanetakis et al., 2014).

Emergent epidemics caused by a variety of criniviruses have followed the increase in whitefly populations over the last two decades throughout the world (Wintermantel, 2004, 2010, 2016; Tzanetakis et al., 2014). As a result, GWF populations have been hypothesized as one of the main drivers of PYVV re-emergence. Therefore, efforts and resources aimed to control the PYVV epidemic have been focused on controlling GWF populations (ICA, 2014; Learmonth, 2014; Tzanetakis et al., 2014). However, the drivers of PYVV outbreaks and the contribution of GWF populations on the spread of PYVV among potato crops are still not completely understood. Whiteflies are rarely a pest of potato crops, and potato is not its preferred host plant (Learmonth, 2014; CIP, 2016; Godfrey and Haviland, 2016). In addition, whiteflies have low migration rates and reduced inter-crop mobility (van Roermund et al., 1997; Brown and Czosnek, 2002; Whitfield et al., 2015). Furthermore, the presence of the virus has been reported in crops located over 3,000 meters above mean sea level (MAMSL) (Saldarriaga et al., 1988; Franco-Lara et al., 2013), beyond the typical altitude range of the GWF (Byrne and Bellows, 1991; Brown and Czosnek, 2002; Cardona et al., 2005).

Colombia has been one of the countries more severely affected by the re-emergent PYVV epidemic (Salazar et al., 2000; FrancoLara et al., 2013). Colombia has a complex geographic landscape composed of five natural regions. The largest region, the Andes mountain region, covers a sizeable portion the country. Potato production systems in Colombia are widespread along the Andes, with potato-producing farms spanning a wide altitude range, from approximately 1,000 to 4,000 MAMSL (DANE, 2002). This geographical feature of the potato production system in Colombia, along with the altitude restriction of the GWF home range, generate a unique environment for a natural experiment to assess the association between the vector GWF and the PYVV epidemic.

Against this background, this study aims to assess the role of GWF as a driver of the PYVV epidemic in the potato-producing areas of Colombia. Using a novel epidemiological approach that incorporates spatial statistical methods and Geographical Information System (GIS) techniques, we aim to identify geographical areas where the PYVV epidemic is concentrated and geographical clusters of farms affected by GWF. In addition, we aim to assess the influence of altitude on the association between PYVV and GWF.

\section{MATERIALS AND METHODS}

\section{Field Sampling and Data Collection}

Potato-producing areas in Colombia were sampled for 1 year between 2013 and 2014. Potato farms were selected using a stratified three-stage random cluster sampling process. Colombia is divided geographically into 32 departments, and nine departments where potato production occurs were selected in the first stage of sampling. In the second stage, 47 municipalities from selected departments were included in the survey. In the final stage of sampling, 569 potato farms from these municipalities were randomly selected with a sample size proportional to the area planted with potato crops in the selected departments, as established by the National Potato Crop Census of Colombia (DANE, 2002). The survey collected data related to the geographic location and altitude of each potato farm, determined through global positioning system (GPS) coordinates.

To determine the presence of GWF, five sampling stations were established in each of the 569 potato farms. The first station was located at the center of the plot, and the other four stations were placed $20 \mathrm{~m}$ from the center and equidistant to each other. Each sampling station contained 10 plants, in which the presence/absence of GWF adults and nymphs was recorded.

To detect the presence of PYVV, a bulk sample made of 100 leaflets from 100 randomly chosen plants from each sampled potato plot was collected. Each bulk sample was divided into five sub-samples and stored at $-20^{\circ} \mathrm{C}$ until processing. Total RNA was extracted after grinding the leaflets with liquid nitrogen, using Trizol ${ }^{\circledR}$ reagent (Invitrogen ${ }^{\circledR}$ ) according to manufacturer directions. The presence of PYVV was determined by reverse transcriptase polymerase chain reaction (RT-PCR), using primers designed for detection of the coat protein (CP) gene of PYVV (F2/3') (Rodríguez et al., 2009). Briefly, the first strand of cDNA was synthesized using $50 \mathrm{ng}$ of total RNA, $50 \mathrm{U}$ of MMLV reverse transcriptase (Invitrogen ${ }^{\circledR}$ ), and $0.5 \mu \mathrm{M}$ of primer $3^{\prime}$ (Rodríguez et al., 2009). For the PCR, $1.6 \mu \mathrm{l}$ of cDNA, $10 \mu \mathrm{M}$ of each primer $\left(\mathrm{F} 2 / 3^{\prime}\right), 2.5 \mathrm{mM}$ of $\mathrm{MgCl}_{2}$, and $1 \mathrm{U}$ of GoTaq DNA polymerase (Promega ${ }^{\circledR}$ ) were mixed in a final volume of $10 \mu \mathrm{L}$. The following program was used for amplification: initial denaturation at $94^{\circ} \mathrm{C}$ 
for $3 \mathrm{~min}$, followed by 35 cycles of denaturation at $94^{\circ} \mathrm{C}$ for $1 \mathrm{~min}$, annealing at $55^{\circ} \mathrm{C}$ for $1 \mathrm{~min}$ and extension at $72^{\circ} \mathrm{C}$ for $1 \mathrm{~min}$, and a final extension at $72^{\circ} \mathrm{C}$ for $10 \mathrm{~min}$. PCR products were visualized on $1 \%$ agarose gels (Invitrogen ${ }^{\circledR}$ ) stained with $\mathrm{SYBR}^{\circledR}$ safe (Invitrogen ${ }^{\circledR}$ ), and the presence of a single $759 \mathrm{bp}$ band was reported as a positive result for the presence of PYVV in each sample. A leaf sample of Solanum phureja cv. "Criolla Colombia" expressing yellowing symptoms (PYVV positive confirmed by RT-PCR) was used as a positive control, and an in vitro potato virus-free leaf sample (obtained by in vitro meristem culture) was used as a negative control.

\section{Spatial Clustering Analysis}

Two spatial clustering analyses were conducted. The first analysis identified geographical clusters of potato farms reporting the presence of PYVV and the second analysis identified clusters of farms reporting the presence of GWF. Both analyses were conducted using spatial scan statistics (Kulldorff, 1997), implemented in the SaTScan software version 9.4 (Kulldorff et al., 2005; Kulldorff, 2010). Scan statistics are among the most widely used methods for spatial cluster detection. They have been successfully used to support scientific research in epidemiology (Kulldorff et al., 2006; Ryan et al., 2006; Wand and Ramjee, 2010; Cuadros et al., 2013; Jones et al., 2013; Malleson and Andresen, 2015; Ruiz-Grosso et al., 2016). However, only few studies in plant pathology have implemented this methodology (e.g., Coulston and Riitters, 2003; Porcasi et al., 2006; Bayon et al., 2007).

In general, spatial scan statistical analysis locates areas with higher (or lower) numbers of cases than expected under spatial randomness (i.e., cases are uniformly distributed throughout the region). We used separate spatial scan statistical analyses to locate clusters of potato farms where the occurrence of PYVV and GWF is greater than expected by random chance. Briefly, scan statistical analysis uses a computer-intensive search by traversing the study region with a circular scanning window to identify any locations where cases are clustered in space (i.e., locations where there are more cases inside than outside the circular window, under the assumption spatial randomness) (Kulldorff, 2010). By continually varying the radius and center, the procedure produces a very large number of circular windows and therefore a very large number of locations is tested for clustering. A likelihood ratio test was used to determine the statistical significance against the null hypothesis of spatial randomness. Clusters with $P<0.05$, calculated through Monte Carlo simulations (using the SaTScan default value of 999 iterations), were classified as statistically significant clusters of farms testing positive for presence of PYVV or farms where the presence of GWF was reported. Relative risks were calculated as the observed prevalence of PYVV (or GWF) divided by the expected prevalence of PYVV (or GWF) assuming spatial randomness, both within the scanning window and outside it.

\section{Statistical Analysis}

The statistical analysis was divided into two phases. First, separate simple linear regression models were fitted to assess the association between altitude and the percentage of farms affected by GWF or PYVV. The slopes from both regressions were compared to identify statistically significant differences between them. For the second phase, three simple logistic regression models were fitted using the dichotomous viral status of the farm (i.e., if the farm was affected by PYVV or not) as the dependent variable and the dichotomous GWF status as the predictor variable. All sampled farms were included in the first logistic regression analysis. In the second analysis, only farms located at an altitude lower than 3,000 MAMSL were included. The last analysis included only farms located at or above 3,000 MAMSL.

To estimate the proportion of PYVV positive farms that could be attributed to the presence of GWF, a population attributable fraction (PAF) was conducted using the following equation (Rockhill et al., 1998),

$$
\frac{p_{e}(R R-1)}{p_{e}(R R-1)+1}
$$

where $p_{e}$ indicates the proportion of source population exposed to the factor of interest (proportion of farms with GWF), and $R R$ is the relative risk of PYVV comparing farms exposed to GWF to farms not exposed to GWF. Statistical analyses were conducted using SAS version 9.3 (SAS, 2006), and all GIS analyses and cartographic displays were performed with ArcGIS version 10.3 (ESRI, 2004).

\section{RESULTS}

\section{Prevalence of PYVV and GWF in Farms}

A total of 569 farms were included in the sample, from which 229 (39.7\%) were located at 3,000 MAMSL or higher (Figure 1A). PYVV was detected in 250 (43.9\%) farms, while GWF was reported in 131 (23.1\%) farms. The simultaneous presence of PYVV and GWF was reported in 98 (17.2\%) farms (Table 1). Antioquia department was the most severely affected by PYVV and GWF. The majority of farms sampled in this department (71.4\%) also reported the co-occurrence of both organisms (Table 2).

More than $60 \%$ of the sampled farms were located in the departments of Boyacá and Cundinamarca. These departments had low prevalence of GWF, with only 16.5 and $12.4 \%$ of the farms reporting the presence of the insect in Boyacá and Cundinamarca, respectively. The presence of PYVV was also low in farms sampled in Boyacá (26.8\%), but it was relatively high in farms sampled in Cundinamarca (42.2\%) (Table 2).

\section{Spatial Clustering Analysis}

Using spatial scan statistics, we identified two geographical clusters with high numbers of farms where GWF was reported, and three clusters with high numbers of farms affected by PYVV (Table 3). Although the three clusters identified by the PYVV analysis contained only $26.1 \%$ of the total number of farms in the survey, the majority (52.0\%) of farms affected by PYVV were in these clusters. Similarly, the two clusters of GWF-affected farms contained $9.4 \%$ of the total number of potato farms in the survey, but $36.7 \%$ of farms where the presence of whitefly was reported were in these clusters. 

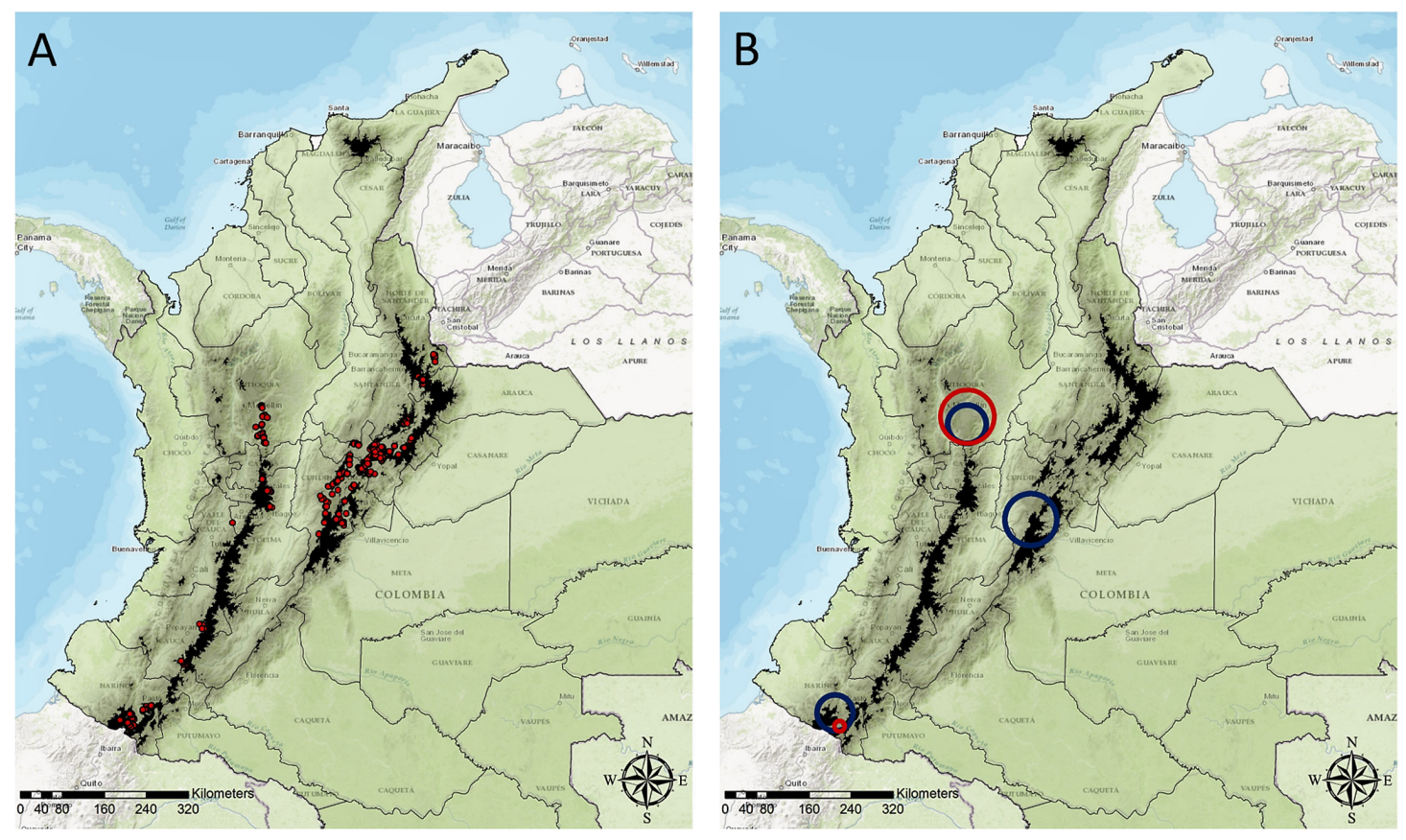

FIGURE 1 | Administrative map of Colombia delineating the different departments, locations of sampled farms, and results of spatial scan statistics analysis. Dark shadowed regions highlight areas above 3000 MAMSL. (A) Locations of the 569 farms included in the study. (B) Locations of clusters with high numbers of farms where the presence of GWF was reported (red circles), and clusters with high numbers of farms affected by PYW (blue circles).

TABLE 1 | Percentage of farms affected by the greenhouse whitefly (GWF) and the potato yellow vein virus (PYW).

\begin{tabular}{|c|c|c|c|c|c|c|}
\hline & \multicolumn{2}{|c|}{ GWF } & \multicolumn{2}{|c|}{ PYVV } & \multicolumn{2}{|c|}{ GWF in PYVV affected farms } \\
\hline & Presence (\%) & Absence (\%) & Presence (\%) & Absence (\%) & Presence (\%) & Absence (\%) \\
\hline Total number of farms & $131(23.1)$ & 438 (76.9) & 250 (43.9) & $319(56.1)$ & 98 (39.2) & $152(60.8)$ \\
\hline $\begin{array}{l}\text { Farms at low elevation } \\
(<3000 \text { MAMSL) }\end{array}$ & $119(35.0)$ & $221(65.0)$ & $179(52.6)$ & $161(47.4)$ & $92(51.4)$ & 87 (48.6) \\
\hline $\begin{array}{l}\text { Farms at high elevation } \\
(>=3000 \mathrm{MAMSL})\end{array}$ & $12(5.2)$ & $217(94.8)$ & $71(31.0)$ & $158(69.0)$ & $6(8.5)$ & $65(91.5)$ \\
\hline
\end{tabular}

TABLE 2 | Presence of the greenhouse whitefly (GWF) and the potato yellow vein virus (PYW) in the nine potato-producing departments in Colombia.

\begin{tabular}{|c|c|c|c|c|c|}
\hline Department & $\begin{array}{l}\text { Mean altitude } \\
\text { of sampled } \\
\text { farms (MAMSL) }\end{array}$ & $\begin{array}{c}\text { Total } \\
\text { number of } \\
\text { sampled farms }\end{array}$ & $\begin{array}{c}\text { Number of } \\
\text { farms affected } \\
\text { by PYVV (\%) }\end{array}$ & $\begin{array}{c}\text { Numbers of } \\
\text { farms affected } \\
\text { by GWF (\%) }\end{array}$ & $\begin{array}{c}\text { Simultaneous } \\
\text { presence of } \\
\text { PYVV and GWF (\%) }\end{array}$ \\
\hline Antioquia & 2363 & 42 & 36 (85.7\%) & $36(85.7 \%)$ & 30 (71.4\%) \\
\hline Boyacá & 2988 & 224 & 60 (26.8\%) & 37 (16.5\%) & 23 (10.3\%) \\
\hline Caldas & 3712 & 7 & $0(0.0 \%)$ & $0(0.0 \%)$ & $0(0.0 \%)$ \\
\hline Cauca & 3082 & 20 & 5 (25.0\%) & $3(15.0 \%)$ & $0(0.0 \%)$ \\
\hline Cundinamarca & 2931 & 161 & $68(42.2 \%)$ & $20(12.4 \%)$ & $13(8.1 \%)$ \\
\hline Nariño & 2931 & 77 & $68(88.3 \%)$ & $29(37.7 \%)$ & $28(36.3 \%)$ \\
\hline Norte de Santander & 2565 & 12 & $5(41.7 \%)$ & $4(33.3 \%)$ & $3(25.0 \%)$ \\
\hline Santander & 3248 & 14 & $6(42.9 \%)$ & $1(7.1 \%)$ & $1(7.1 \%)$ \\
\hline Tolima & 3101 & 12 & 2 (16.7\%) & 1 (8.3\%) & $0(0.0 \%)$ \\
\hline
\end{tabular}

A cluster of GWF-affected farms and a cluster of PYVVpositive farms overlapped in Antioquia department (Figure 1B). These clusters had very high numbers of farms where the presence of GWF was reported (87.1\%), and farms affected by PYVV (88.4\%). A small cluster of GWF-affected farms was also detected in Nariño department, and this cluster was contained 


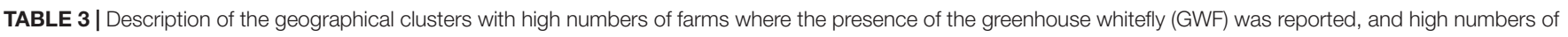
farms affected by and the potato yellow vein virus (PYW).

\begin{tabular}{|c|c|c|c|c|c|c|c|c|}
\hline $\begin{array}{l}\text { Cluster } \\
\text { number }\end{array}$ & $\begin{array}{c}\text { Radius } \\
\text { (Km) }\end{array}$ & $\begin{array}{c}P \text { - } \\
\text { value }\end{array}$ & $\begin{array}{c}\text { Number of } \\
\text { farms inside } \\
\text { the cluster }\end{array}$ & $\begin{array}{c}\text { Observed } \\
\text { number of } \\
\text { farms affected }\end{array}$ & $\begin{array}{c}\text { Expected } \\
\text { Number of } \\
\text { farms affected }\end{array}$ & $\begin{array}{c}\text { Relative } \\
\text { risk }\end{array}$ & $\begin{array}{l}\text { Percentage } \\
\text { of farms } \\
\text { affected (\%) }\end{array}$ & $\begin{array}{l}\text { Percentage } \\
\text { of presence } \\
\text { of GWF (\%) }\end{array}$ \\
\hline \multicolumn{9}{|c|}{ Clusters with high numbers of farms where the presence of GWF was reported } \\
\hline 1 & 72.9 & $<0.001$ & 42 & 36 & 10 & 4.8 & 85.7 & \\
\hline 2 & 10.3 & $<0.001$ & 12 & 12 & 3 & 4.7 & 100.0 & \\
\hline \multicolumn{9}{|c|}{ Clusters with high numbers of farms affected by PYW } \\
\hline 1 & 34.2 & $<0.001$ & 71 & 65 & 31 & 2.5 & 91.5 & 41.4 \\
\hline 2 & 36.5 & $<0.001$ & 40 & 36 & 18 & 2.2 & 90.0 & 85.7 \\
\hline 3 & 49.3 & 0.01 & 37 & 29 & 16 & 1.9 & 78.4 & 42.1 \\
\hline
\end{tabular}

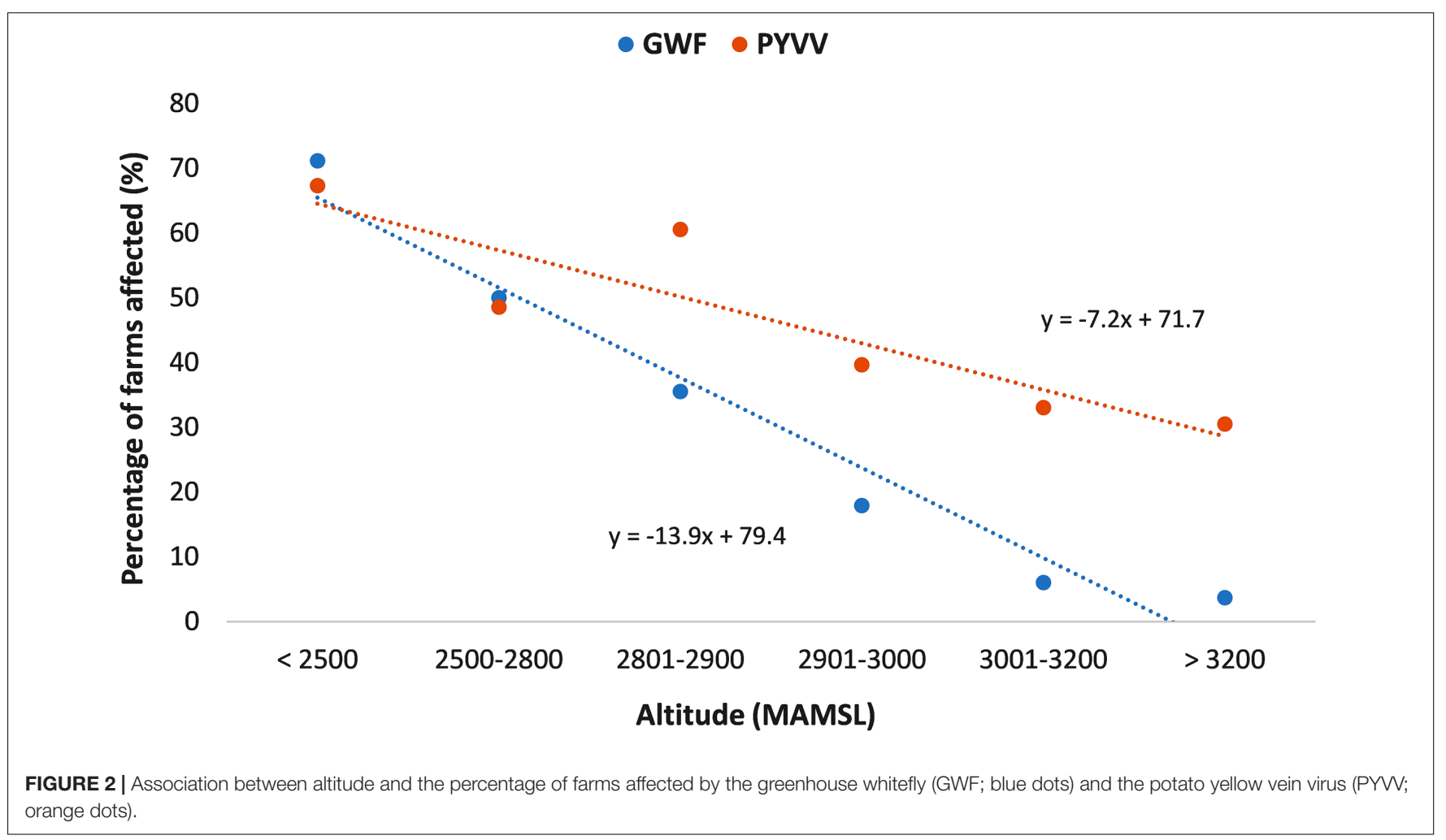

within a much larger cluster of farms affected by PYVV identified in the same area. A third cluster of PYVV-positive farms was located in Cundinamarca department, with PYVV reported in $78.4 \%$ of the sampled farms. This cluster did not overlap with a cluster of GWF-affected farms.

\section{Statistical Analysis}

Simple linear regression analysis indicated a statistically significant negative association between altitude and both the percentage of farms affected by PYVV and the percentage of farms affected by GWF (Figure 2). However, comparison of the slopes from both regressions indicated a significantly stronger association between altitude and the presence of GWF compared to the association with presence of PYVV $(P=0.01)$.

More than $50 \%$ of the farms located below 3,000 MAMSL were affected by both GWF and PYVV. However, GWF was reported in less than $6 \%$ of the farms located above 3,000 MAMSL. In contrast, the presence of PYVV persisted at high altitudes, with $31 \%$ of the farms located above 3,000 MAMSL testing positive for its presence (Table 1).

Farms in which the presence of GWF was reported had almost three times higher odds of being PYVV-positive (Model 1 in Table 4; OR $=2.6,95 \%$ confidence interval [CI] 1.93.5) compared to farms where the insect was not detected. Similar odds were obtained when including only farms located below 3,000 MAMSL (Model 2 in Table 4; OR $=2.7$, 95\% CI 1.9-3.8). However, the presence of GWF was not significantly associated with PYVV in farms located above 3,000 MAMSL (Model 3 in Table 4; OR $=1.4$, 95\% CI 0.8-2.5). Results from the PAF analysis indicated that GWF populations could be directly responsible for only $27 \%$ of the total number of farms affected by PYVV. 
TABLE 4 | Results from the regression analysis assessing the association between the potato yellow vein virus (PYW) and the greenhouse whitefly (GWF) presence.

\begin{tabular}{|c|c|c|c|}
\hline & Odds ratio & $95 \% \mathrm{Cl}$ & $P$-value \\
\hline \multicolumn{4}{|c|}{ Model 1 - Total number of farms } \\
\hline Absence of GWF & Ref* & & \\
\hline Presence of GWF & 2.6 & $1.9-3.5$ & $<0.005$ \\
\hline \multicolumn{4}{|c|}{ Model 2 - Farms at low elevation (<3000 MAMSL) } \\
\hline Absence of GWF & Ref* & & \\
\hline Presence of GWF & 2.7 & $1.9-3.8$ & $<0.005$ \\
\hline \multicolumn{4}{|c|}{ Model 3 - Farms at high elevation (> = 3000 MAMSL) } \\
\hline Absence of GWF & Ref* & & \\
\hline Presence of GWF & 1.4 & $0.8-2.5$ & 0.24 \\
\hline
\end{tabular}

The outcome of the regression is PYW infection.

*Reference group.

\section{DISCUSSION}

According to our results, the PYVV epidemic in Colombia is geographically clustered in three departments: Antioquia, Cundinamarca, and Nariño. The clusters identified in these departments enclosed more than half of the PYVV-positive farms. Still, only a single cluster with a higher number of farms reporting the presence of GWF was found to overlap a cluster of PYVV-positive farms. The overlapping clusters were found in Antioquia, the department where most farms reported the presence of both organisms. Conversely, the largest cluster of PYVV-positive farms identified was located in Cundinamarca, a department that also had the lowest percentage of farms where the presence of the GWF was reported. Potato crops from this department were located at high altitude, at an average of 2,970 MAMSL (Range $=2,171-3,444$ MAMSL), compared to crops from Antioquia, which were located at an average altitude of 2,355 MAMSL (Range $=2,130-2,552$ MAMSL).

We found that altitude could be an important factor modulating the association between PYVV and GWF populations. Despite the statistically significant association between PYVV and the presence of whitefly reported in Model 1 (all farms included), when only farms located at 3,000 MAMSL or higher were considered (Model 3), this association was no longer significant. Furthermore, there was a strong negative association between altitude and the presence of the GWF, in which the GWF was almost absent above 3,000 MAMSL. Although PYVV was also negatively associated with altitude, the virus was detected in more than $30 \%$ of the farms located above 3,000 MAMSL, suggesting that altitude has a stronger negative effect on GWF that on PYVV.

Epidemics caused by viruses such as PYVV could have a more complex natural history than a simple vectorborne transmission. Vector transmission of PYVV might have an important role in virus dispersion, but could fail to explain the extent of the virus epidemic observed in Colombia. In fact, we estimated that the presence of GWF populations could only explain $27 \%$ of the total PYVV epidemic in this country. Therefore, other mechanisms of virus dispersion could be driving the PYVV epidemic, particularly at high elevations above the typical range of the GWF distribution.

Viruses such as PYVV have also been reported to be dispersed through vegetative propagules (Salazar et al., 2000; Sastry, 2013), which could be an efficient mechanism of long-distance dispersion boosted by human transportation of infected tubers. According to official data, less than $5 \%$ of the area planted with potatoes in Colombia comes from certified seed tubers, and even when seeds are certified, they are not currently tested for PYVV infection (Fedepapa, 2016). Without an adequate seed certification system, informal trade in seed potatoes might provide a key pathway for long-distance virus dissemination, expanding significantly the range of virus dispersion, and becoming a major driver of the epidemic. In addition, it is possible that short-distance dispersion could be stimulated by the distinct yellow color symptoms caused by the virus infection, fueling the ongoing dispersion by attracting GWF populations (Moreau and Isman, 2011). After the establishment of the infection, vector transmission could then become an efficient short-distance mechanism of virus dispersion to other plants within the farm and along the surrounding neighboring crops.

Despite the strengths of our study, a number of limitations are worth noting. First, although a well-developed and validated sampling method was implemented (same within-farm sample size is used for seed tuber certification in several countries), PYVV is commonly distributed irregularly across plants in the field. Therefore, the presence of the virus could have been missed and not reported in some affected farms. Similarly, relying on a reverse-transcriptase PCR protocol for detection of plant pathogens can sometimes lead to misdiagnosis due to very low titer, presence of PCR inhibitors or post-PCR contamination (Wisler et al., 1998; Mumford et al., 2000). However, we tried to minimize these risks in our study, utilizing more reliable primers and an optimized protocol for the amplification of the highly genetically stable coat protein of PYVV, and running a set of positive and negative controls in all the experimental procedures (López et al., 2006). Moreover, this was a cross-sectional study, and temporal changes in both GWF populations and the PYVV epidemic were not captured. Temporal information could provide more insights about the causal relationship between PYVV and GWF as well as their temporal dynamics. Lastly, variables such as tuber origin (i.e., if certified seed was used or not) would have improved our assessment of the association between the PYVV epidemic and viral dispersion through vegetative propagules. Although our survey originally included this variable, we later considered that the information collected on seed tuber origin was unreliable. The rate of potato farmers reporting certified seed tubers estimated was substantially above the official reported rate ( $<5 \%$ official rate vs. $15 \%$ reported by farmers in this study). Likewise, current seed tuber certification in Colombia does not include tests for PYVV infection.

Despite these limitations, this is the first study, to our knowledge, that investigates the spatial structure of the PYVV epidemic as well as the association between the virus and its insect vector at a national scale. Outbreaks of GWF populations have been proposed as directly responsible for the recent PYVV 
re-emergence in Colombia, and efforts have been focused on controlling the insect vector populations. However, without a comprehensive understanding of the epidemic dynamics as well as the main drivers of the viral dispersion, resources to control the epidemic could be mistakenly allocated into interventions that might not be the most effective, and might also cause detrimental economic and environmental impacts. Here, using a large nationally representative sample of potato farms in Colombia, we found that GWF populations can only explain a small fraction of the extent of the PYVV epidemic in the country. Movement of infected vegetative propagules might be the main mechanism of dispersion, and could be a key driver for virus epidemics such as PYVV in agricultural systems. Therefore, designing agricultural policies focused on improving and certifying the quality of tubers and their appropriate distribution could be the most efficient control intervention against virus dispersion.

\section{AUTHOR CONTRIBUTIONS}

DR and DC conceived the study and its design, conducted the statistical and spatial modeling analyses, and wrote the

\section{REFERENCES}

Barragan, C. E., and Guzmán-Barney, M. (2014). Molecular detection of Potato yellow vein virus in the natural whitefly vector Trialeurodes vaporariorum, Westwood. Rev. Prot. Veg. 29, 168-176.

Bayon, C., Pei, M., Ruiz, C., and Hunter, T. (2007). Genetic structure and spatial distribution of the mycoparasite Sphaerellopsis filum on Melampsora lariciepitea in a short-rotation coppice willow planting. Plant Pathol. 56, 616-623. doi: 10.1111/j.1365-3059.2007.01606.x

Brown, J. K., and Czosnek, H. (2002). Whitefly transmission of plant viruses. $A d v$. Bot. Res. 36, 65-100. doi: 10.1016/S0065-2296(02)36059-2

Byrne, D. N., and Bellows, T. S. Jr. (1991). Whitefly biology. Annu. Rev. Entomol. 36, 431-457. doi: 10.1146/annurev.en.36.010191.002243

Cardona, C., López-Avila, A., and Valarezo, O. (2005). “Colombia and ecuador," in Whitefly and Whitefly-borne Viruses in the Tropics: Building a Knowledge Base for Global Action, eds P. Anderson and F. Morales (Cali: Centro Internacional de Agricultura Tropical), 274-284.

CIP (2016). Potato Pest and Diseases. Available at: http://cipotato.org/potato/pestsdiseases/

Coulston, J. W., and Riitters, K. H. (2003). Geographic analysis of forest health indicators using spatial scan statistics. Environ. Manag. 31, 764-773. doi: 10.1007/s00267-002-0023-9

Cuadros, D. F., Awad, S. F., and Abu-Raddad, L. J. (2013). Mapping HIV clustering: a strategy for identifying populations at high risk of HIV infection in subSaharan Africa. Int. J. Health Geogr. 12:28. doi: 10.1186/1476-072X-12-28

Chávez, P., Zorogastúa, P., Chuquillanqui, C., Salazar, L., Mares, V., and Quiroz, R. (2009). Assessing Potato yellow vein virus (PYVV) infection using remotely sensed data. Int. J. Pest Manag. 55, 251-256. doi: 10.1080/09670870902862685

DANE (2002). Censo Nacional del Cultivo de Papa 2002. Available at: http:// bibliotecadigital.agronet.gov.co/bitstream/11348/4580/1/016.pdf

ESRI (2004). ArcGIS 9.x. Redlands, CA: ESRI.

Fedepapa (2016). Plan Estratégico 2020. Available at: http://www.fedepapa.com/ recursos/Documento\%20estrat\%C3\%A9gico\%20Plan\%202020.pdf

Franco-Lara, L., Rodríguez, D., and Guzmán-Barney, M. (2013). Prevalence of Potato yellow vein virus (PYVV) in Solanum tuberosum group Phureja fields in three states of Colombia. Am. J. Potato Res. 90, 324-330. doi: 10.1007/s12230013-9308-1

Godfrey, L., and Haviland, D. (2016). UC IPM Pest Management Guidelines-Potato. Available at: http://ipm.ucanr.edu/PMG/r607300711.html first draft of the paper. AH and DT contributed to study conception and design, molecular analysis, interpretation of the results, and writing of the manuscript. $\mathrm{AB}$ and $\mathrm{MT}$ contributed to study conception and design, conduct of the statistical modeling analyses, interpretation of the results, and writing of the manuscript.

\section{FUNDING}

This study was funded by Corporación Colombiana de Investigación Agropecuaria (Corpoica) and the Colombian Ministry of Agriculture (Grant: "Generación y validación de tecnologías sostenibles de producción para incrementar la competitividad de la cadena de la papa en Colombia").

\section{ACKNOWLEDGMENTS}

We thank Dr. Olga Perez for gently providing the datasets that made possible this contribution. Research support was provided by government funds appropriated to Corpoica.

ICA (2014). Resolución 4213 de 2014. Available at: http://extwprlegs1.fao.org/docs/ pdf/col144725.pdf

Jones, P., Gunnell, D., Platt, S., Scourfield, J., Lloyd, K., Huxley, P., et al. (2013). Identifying probable suicide clusters in Wales using national mortality data. PLOS ONE 8:e71713. doi: 10.1371/journal.pone.0071713

Kulldorff, M. (1997). A spatial scan statistic. Commun. Stat. Theory Methods 26, 1481-1496. doi: 10.1080/03610929708831995

Kulldorff, M. (2010). SaTScan v9.0: Software for the Spatial and Space-Time Statistics. Available at: https://www.satscan.org/

Kulldorff, M., Heffernan, R., Hartman, J., Assunção, R., and Mostashari, F. (2005). A space-time permutation scan statistic for disease outbreak detection. PLOS Med 2:e59. doi: 10.1371/journal.pmed.0020059

Kulldorff, M., Song, C., Gregoria, D., Samociuk, H., and DeChello, L. (2006). Cancer map patterns: are they random or not? Am. J. Prev. Med. 30, s37-s49. doi: 10.1016/j.amepre.2005.09.009

Learmonth, S. (2014). Whitefly: Potato and Cabbage Pest in Indonesia and Western Australia. Available at: https://www.agric.wa.gov.au/cabbage/whitefly-potatoand-cabbage-pest-indonesia-and-western-australia

López, R., Asensio, C., Guzman, M., and Boonham, N. (2006). Development of real-time and conventional RT-PCR assays for the detection of Potato yellow vein virus (PYVV). J. Virol. Methods 136, 24-29. doi: 10.1016/j.jviromet.2006. 03.026

Malleson, N., and Andresen, M. A. (2015). Spatio-temporal crime hotspots and the ambient population. Crime science 4:10. doi: 10.1186/s40163-0150023-8

Moreau, T. L., and Isman, M. B. (2011). Trapping whiteflies? A comparison of greenhouse whitefly (Trialeurodes vaporariorum) responses to trap crops and yellow sticky traps. Pest. Manag. Sci. 67, 408-413. doi: 10.1002/ps.2078

Mumford, R., Walsh, K., Barker, I., and Boonham, N. (2000). Detection of Potato mop top virus and Tobacco rattle virus using a multiplex real-time fluorescent reverse-transcription polymerase chain reaction assay. Phytopathology 90, 448-453. doi: 10.1094/PHYTO.2000.90.5.448

Porcasi, X., Catalá, S., Hrellac, H., Scavuzzo, M., and Gorla, D. (2006). Infestation of rural houses by Triatoma infestans (Hemiptera: Reduviidae) in southern area of Gran Chaco in Argentina. J. Med. Entomol. 43, 1060-1067. doi: 10.1093/ jmedent/43.5.1060

Rockhill, B., Newman, B., and Weinberg, C. (1998). Use and misuse of population attributable fractions. Am. J. Public Health 88, 15-19. doi: 10.2105/AJPH. 88.1.15 
Rodríguez, P., Cháves, G., Franco, L., and Guzmán, M. (2009). "Low molecular variability of Potato yellow vein virus (PYVV) isolates of Solanum phureja and Solanum tuberosum from Colombia," in Proceedings of the Joint Meeting of the Florida Phytopathological Society and the American Phytopathological Society Caribbean Division, Orlando, FL.

Ruiz-Grosso, P., Miranda, J. J., Gilman, R. H., Walker, B. B., CarrascoEscobar, G., Varela-Gaona, M., et al. (2016). Spatial distribution of individuals with symptoms of depression in a periurban area in Lima: an example from Peru. Ann. Epidemiol. 26, 93-99. doi: 10.1016/j.annepidem.2015. 11.002

Ryan, J., Mbui, J., Rashid, J., Wasunna, M., Kirigi, G., Magiri, C., et al. (2006). Spatial clustering and epidemiological aspects of visceral Leishmaniasis in two endemic villages, Baringo District, Kenya. Am. J. Trop. Med. Hyg. 74, 308-317.

Salazar, L. F., Muller, G., Querci, M., Zapata, J. L., and Owens, R. A. (2000). Potato yellow vein virus: its host range, distribution in South America and identification as a crinivirus transmitted by Trialeurodes vaporariorum. Ann. Appl. Biol. 137, 7-19. doi: 10.1111/j.1744-7348.2000.tb00052.x

Saldarriaga, A., Alvarez, A. M., and Jaramillo, J. E. (1988). Efecto del amarillamiento de venas transmitido por Trialeurodes vaporariorum (Westwood) en papa. Rev. Colomb. Entomol. 14, 3-8.

SAS (2006). SAS. Cary, NC: SAS Instituter Inc.

Sastry, K. S. (2013). "Plant virus transmission through vegetative Propagules (Asexual Reproduction)," in Seed-Borne Plant Virus Diseases, ed. K. S. Sastry (New Delhi: Springer), 285-305. doi: 10.1007/978-81-322-0813-6_9

Tzanetakis, I. E., Martin, R. R., and Wintermantel, W. M. (2014). Epidemiology of criniviruses: an emerging problem in world agriculture. Front. Microbiol. 4:119. doi: 10.3389/fmicb.2013.00119

van Roermund, H. J. W., van Lenteren, J. C., and Rabbinge, R. (1997). Biological control of greenhouse whitefly with the parasitoid Encarsia formosa on tomato: an individual-based simulation approach. Biol. Control 9, 25-47. doi: 10.1006/ bcon.1997.0512
Wand, H., and Ramjee, G. (2010). Targeting the hotspots: investigating spatial and demographic variations in HIV infection in small communities in South Africa. J. Int. AIDS Soc. 13:41. doi: 10.1186/1758-2652-13-41

Whitfield, A. E., Falk, B. W., and Rotenberg, D. (2015). Insect vector-mediated transmission of plant viruses. Virology 479, 278-289. doi: 10.1016/j.virol.2015. 03.026

Wintermantel, W. (2016). "Semipersistent whitefly-transmitted viruses: criniviruses," in Vector-Mediated Transmission of Plant Pathogens, ed. M. W. William (Saint Paul, MN: The American Phytopathological Society), 111-119. doi: 10.1094/9780890545355.008

Wintermantel, W. M. (2004). Emergence of Greenhouse Whitefly (Trialeurodes vaporariorum) Transmitted Criniviruses as Threats to Vegetable and Fruit Production in North America. Available at: http://www.apsnet.org/publications/ apsnetfeatures/Documents/2004/GreenhouseWhitefly.pdf

Wintermantel, W. M. (2010). "Transmission efficiency and epidemiology of criniviruses," in Bemisia: Bionomics and Management of a Global Pest, eds P. A. Stansly and S. E. Naranjo (Dordrecht: Springer), 319-331.

Wisler, G., Duffus, J., Liu, H.-Y., and Li, R. (1998). Ecology and epidemiology of whitefly-transmitted closteroviruses. Plant Dis. 82, 270-280. doi: 10.1094/ PDIS.1998.82.3.270

Conflict of Interest Statement: The authors declare that the research was conducted in the absence of any commercial or financial relationships that could be construed as a potential conflict of interest.

Copyright (c) 2017 Cuadros, Hernandez, Torres, Torres, Branscum and Rincon. This is an open-access article distributed under the terms of the Creative Commons Attribution License (CC BY). The use, distribution or reproduction in other forums is permitted, provided the original author(s) or licensor are credited and that the original publication in this journal is cited, in accordance with accepted academic practice. No use, distribution or reproduction is permitted which does not comply with these terms. 